УДК 373.1:373.5(477)

Пастовенський Олександр Вікторович

кандидат педагогічних наук, начальник управління освіти і науки

Житомирська обласна державна адміністрація, м. Житомир, Україна

ztedu@ukr.net

\title{
РОЗВИТОК МЕРЕЖНОЇ ВЗАЕМОДІЇ ГРОМАДСЬКИХ І ДЕРЖАВНИХ СТРУКТУР В УПРАВЛІННІ ЗАГАЛЬНОЮ СЕРЕДНЬОЮ ОСВІТОЮ
}

\begin{abstract}
Анотація. У статті розглянуто тенденції розвитку системи управління загальною середньою освітою. Встановлено, що ефективності управління освітніми системами можна досягти на основі делегування управлінських функцій від державних до самоврядних, освітніх i громадських структур. Зроблено висновок, що саме мережна взаємодія громадських управлінських структур 3 владною вертикаллю державних структур, збудованою згори донизу, і вертикаллю самоврядних, збудованою знизу догори, зможуть забезпечити освітнім системам можливості для активного розвитку. Підкреслено, що сучасні хмарні технології виводять мережні взаємодії державних, самоврядних, освітянських і громадських структур в управлінні загальною середньою освітою на якісно новий рівень.
\end{abstract}

Ключові слова: державні; самоврядні; освітні; громадські структури; мережна взаємодія; хмарні технології.

\section{1. ВСТУП}

Постановка проблеми. Нинішні соціально-економічні трансформації в Україні, широка демократизація суспільно-політичного життя, активізація місцевого самоврядування, соціальних мереж зумовлюють необхідність нової освітньої політики, зміну парадигми управління галуззю.

В умовах зростання рівня різноманітності сучасних освітніх систем для досягнення ефективного управління ними необхідно забезпечити децентралізацію управління, поступове перетворення жорсткого субординаційного управління на демократичне, епровадження нових, відкритих моделей управління освітою, які повинні мати як державно-громадський? так і громадсько-державний характер. Наразі важливо передбачити органічне поєднання засобів державного впливу 3 громадським управлінням.

Однак, дотепер недостатньо повно проаналізовано напрям необхідних змін у розподілі повноважень між державними і громадськими структурами, а також в характері їх взаємодії в управлінні загальною середньою освітою в умовах розвитку соціальних систем і сучасних інформаційних технологій.

Аналіз останніх досліджень і публікацій. Дослідженню процесів взаємодії держави і громадськості в управлінні загальною середньою освітою присвячені роботи таких авторів як М. Барбер, Р. Вестбрук, Е. Гутман, Д. Дьюї, Е. Ентвістл, Д. Конант, Дж. Ст. Мілль, Т. Найт, А. Нейл, Н. Акінфієва, В. Бочкарьов, В. Грабовський, В. Гусаров, Л. Даниленко, Г. Єльнікова, О. Зайченко, Л. Калініна, Л. Каменщикова, В. Князєв, Ю. Конаржевский, Т. Лукіна, Н. Протасова, Т. Шамова та інші.

Мета статті полягає в з'ясуванні тенденцій змін у розподілі повноважень між державними, самоврядними, освітніми і громадськими структурами в умовах розвитку освітніх систем і сучасних інформаційних технологій і розробленні на цій основі схеми їх взаємодії в управлінні загальною середньою освітою. 


\section{2. МЕТОДИ ДОСЛІДЖЕННЯ}

Дослідження проводилося у межах комплексної науково-дослідної теми «Теорія і технології організаційних механізмів управління діяльністю загальноосвітніх навчальних закладів» № 0112U000311 Інституту педагогіки Національної академії педагогічних наук України. Під час роботи використовувалися такі методи дослідження: аналіз (у тому числі, ретроспективний), синтез, порівняння - для вивчення наукових праць, нормативно-правової бази з питань освіти і практичного досвіду управління системою загальної середньої освіти в регіоні; узагальнення, класифікація, систематизація - для розроблення схем, оцінювання отриманих результатів.

\section{3. РЕЗУЛЬТАТИ ДОСЛІДЖЕННЯ}

Як стверджують науковці, здатність системи до розвитку забезпечується за рахунок зростання ii міри різноманітності, під чим будемо розуміти число реально існуючих різних елементів системи, їх станів і зв'язків між ними [1]. Утім, зі збільшенням міри різноманітності систем зростають вимоги до їх управлінських підсистем.

Один із засновників кібернетики У. Ешбі сформулював важливу вимогу до сфери управління - принцип необхідної різноманітності, за яким тільки різноманітність може знищити різноманітність [2, с. 293-294]. Як стверджує У. Ешбі, для досягнення ефективності управління різноманітність підсистеми, що управляє, має бути не меншою, ніж різноманітність керованої підсистеми. Щоразу, коли виникає невідповідність між застарілими управлінськими структурами і збільшеною мірою різноманітності керованої системи, відбувається неминуча втрата ефективності управління. Отже, управління може бути ефективним лише за умови, що підсистема, яка управляє, за мірою різноманітності перевершує керовану.

Разом 3 тим, на сучасному етапі соціальні системи динамічно розвиваються й ускладнюються, тому підсистемам управління потрібно на це адекватно реагувати i перебудовуватися відповідно до зростаючої різноманітності керованих підсистем. Причому, як випливає із закону необхідної різноманітності, створення простого i зручного механізму управління не тільки не забезпечить ефективного управління, а спричинить протилежний ефект і може дестабілізувати соціальну систему в цілому. Як підкреслюють науковці, єдиним надійним способом приведення у відповідність керуючих i керованих підсистем $\epsilon$ передавання частини управлінських функцій громадським структурам, які утворилися еволюційним шляхом, а значить, є стійкими $[1 ; 3]$.

Проаналізуємо детальніше ці процеси в освітніх системах. Як свідчить історичний досвід, у другій половині XX століття в країнах колишнього соціалістичного табору переважало державне управління загальною середньою освітою. У цей період центральними органами регламентувалися практично всі сторони життя навчальновиховних закладів. Наразі майже не враховувалися інтереси громадськості. Педагогічні ради, методичні об'єднання педагогів, батьківські збори, органи учнівського самоврядування, які за формою створювалися як громадські органи, також значною мірою перебували під контролем адміністрацій навчальних закладів. Як стверджує аналіз, лише мінімальна частина управлінських рішень дійсно приймалися i реалізовувалися 3 урахуванням думки громадськості. Тобто, система загальної середньої освіти за своєю суттю була практично замкненою системою [4]. 
Водночас, 3 ускладненням суспільного життя, зокрема внутрішніх і зовнішніх процесів в освітніх системах, стала очевидною неефективність управління освітою, що зумовило передачу частини управлінських функцій самоврядним i громадським структурам, зокрема, радам навчальних закладів, піклувальним радам тощо. Це збільшило різноманітність керуючої підсистеми і забезпечило на певному етапі підвищення ефективності управління освітою.

Проте у результаті цього громадські структури, розірвавши фактичну замкненість освітніх систем, увійшли до їх складу, тим самим знову збільшивши міру різноманітності системи загальної середньої освіти в цілому. Єдиним шляхом приведення керуючої підсистеми у відповідність зі збільшеною різноманітністю розширеної системи загальної середньої освіти і забезпечення ефективності управління, як розглядалося вище, може бути передавання наступної частини управлінських функцій самоврядним і громадським структурам, що знову розширить межі освітньої системи та іiі різноманітність і зумовить чергове передавання певних управлінських функцій громадським структурам тощо [4].

Авторську схему приведення у відповідність керуючої і керованої підсистем загальної середньої освіти шляхом передавання управлінських функцій від керуючої підсистеми до громадських структур [4] зображено на рис. 1, де: 1 - керуюча підсистема (керуючі підсистеми зафарбовано сірим кольором, насиченість якого спадає, що демонструє деконцентрацію управління); 2 - керовані освітні підсистеми; 3 - розширення освітніх керуючої і керованої підсистем за рахунок самоврядних i громадських структур, яким передається частина управлінських функцій; вектором $\rightarrow$ зображено напрям передавання управлінських функцій від керуючої підсистеми до самоврядних і громадських структур.

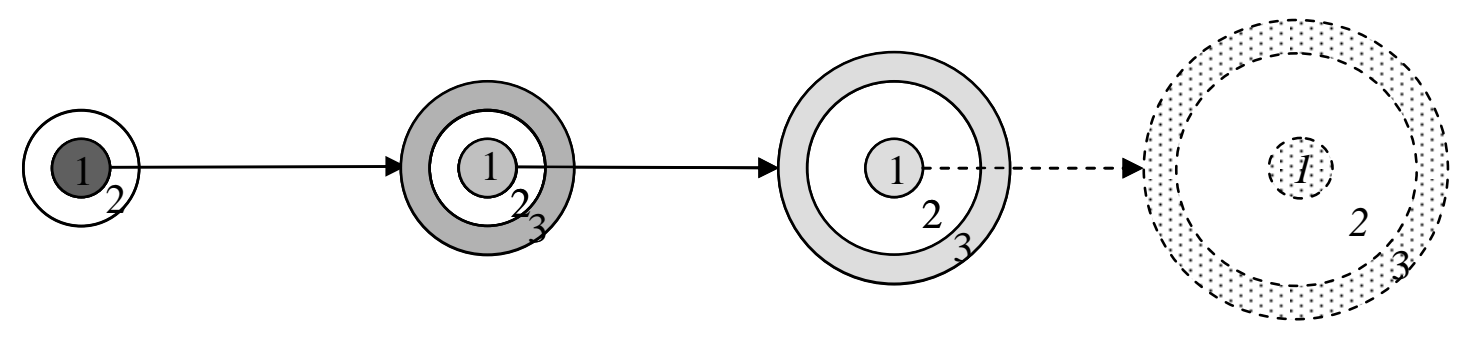

Рис. 1. Схема приведення у відповідність керуючої і керованої підсистем загальної середньої освіти иляхом передавання управлінських функцій від керуючої підсистеми до громадських структур

3 наведеного вище випливає важливий висновок: для підвищення ефективності управління загальною середньою освітою держава має делегувати частину повноважень освітнім і громадським структурам, відмовившись від здійснення управлінських функцій у галузі на регіональному рівні, що, попри все, дасть можливість значно спростити державний управлінський апарат. Як стверджує досвід європейських країн, державі доцільно обмежитися такою управлінською вертикаллю в загальній середній освіті [5]: Президент України $\rightarrow$ Кабінет Міністрів України $\rightarrow$ Міністерство освіти і науки України, які мають здійснювати нормативно-правове регулювання відносин у системі загальної середньої освіти; визначати перспективи іiі розвитку; розробляти, упроваджувати і контролювати додержання Державного стандарту загальної середньої освіти тощо.

Більшість повноважень у галузі загальної середньої освіти (зокрема, щодо розвитку мережі навчальних закладів, їх фінансування, створення необхідної 
матеріально-технічної бази, призначення їх керівників, охорони здоров’я і харчування учнів, соціального захисту учасників навчально-виховного процесу тощо) державі доцільно делегувати місцевому самоврядуванню, яке має також отримати на основі здійснення адміністративно-територіальної реформи реальні матеріальні, фінансові, кадрові тощо ресурси, оскільки представники виборних органів влади, які приймають рішення щодо освітніх питань, $є$ безпосередньо відповідальними перед місцевою громадою, що їх обрала. У системі самоврядних структур існує ефективний механізми впливу громадян на реалізацію освітньої політики: громадяни (виборці) $\rightarrow$ місцева рада $\rightarrow$ місцевий голова $\rightarrow$ виконавчий комітет $\rightarrow$ управління освіти $\rightarrow$ дирекція навчального закладу, тобто, свого роду «вертикаль», збудована знизу догори.

Разом $з$ тим, як показує досвід демократичних країн, місцевому самоврядуванню, у свою чергу, для підвищення ефективності управління загальною середньою освітою доцільно передати значну частину повноважень (особливо щодо організації навчальновиховного процесу, вибору змісту, форм і методів навчання і виховання, призначення i підвищення кваліфікації педагогічних працівників, ефективного використання коштів) безпосередньо навчальним закладам. Водночас, державним і самоврядним органам слід запровадити механізми контролю і підзвітності керівництва закладів, оскільки школи мають нести відповідальність за якість навчання. Такий контроль найефективніше можуть здійснювати громадські структури - об'єднання педагогів, батьків, учнів, небайдужих громадян, які створювалися еволюційним шляхом, $\epsilon$ стабільними, незалежними від бюрократичних впливів і в яких існує зацікавленість у результатах навчання і виховання [5].

Тобто, ефективного управління загальноосвітніми навчальними закладами можна досягти лише на основі делегування управлінських функцій від державних до самоврядних, освітніх і громадських структур. Причому, з розвитком освітніх систем державні органи мають передавати згаданим структурам, перш за все радам навчальних закладів і освітніх округів, усе більше і більше владних повноважень. Однак, як зазначено вище, рада навчального закладу (округу) зможе забезпечити ефективний громадський контроль за якістю освітніх послуг лише у співробітництві з відповідними громадськими структурами, орієнтованими на розв'язання освітніх проблем педагогічними, учнівськими, батьківськими, піклувальними радами, педагогічними товариствами, творчими спілками, благодійними фондами, радами ветеранів, батьківськими і молодіжними асоціаціями тощо.

Водночас, на нашу думку, безпосередня участь численних громадських структур в управлінні навчальними закладами може ускладнити управлінський процес. Тому доцільніше, аби пропозиції добровільних об'єднань освітян, батьків, учнів, зацікавлених у покращенні освіти громадян узагальнювалися відповідно педагогічними, батьківськими, учнівськими, піклувальними радами, а потім надавалися до громадських управлінських структур (рад навчальних закладів або загальних зборів, рад освітніх округів), яким на законодавчому рівні мають бути делеговані відповідні управлінські функції на вирішення найважливіших питань розвитку освітніх систем, зокрема, щодо вибору навчальних програм, затвердження навчальних планів, кошторисів, штатних розписів, стимулювання праці педагогів тощо [5].

Вільний обмін інформацією між усіма зацікавленими громадськими структурами щодо реальних освітніх потреб громадян, пропозицій стосовно можливих шляхів їх задоволення, а також рівня задоволення цих потреб конкретним навчальним закладом сприяє реалізації управлінських функцій контролю і вибудовується за принципом мережного, яке в нинішніх умовах розвитку Інтернету визнано найефективнішим. Мережі мають значну перевагу перед традиційними ієрархічно організованими структурами, оскільки є рухливими й адаптивними, здатними розвиватися разом зі 
своїм оточенням. Такі характеристики, як незалежність членів мережі; об'єднуюча мета; добровільність зв'язків; множинність лідерів і рівнів взаємодії забезпечують у мережах найвищий рівень організації соціальних дій, що здатний забезпечити досягнення синергетичного ефекту [6]. Тому 3 розвитком суспільства мережне управління, у тому числі в освіті, набуватиме все більшого і більшого поширення.

Проте варто зауважити, що мережне управління, зокрема в освітніх системах, не можна сформувати штучно, зверху, за допомогою навіть найдосконаліших схем і алгоритмів. Воно має розвинутися внаслідок еволюційних процесів, шляхом кооперації, самоорганізації та саморозвитку громадських структур, у тому числі, на основі інтенсифікації обміну інформацією між ними. Однак, як стверджує відомий австрійський філософ Ф.А. фон Хайєк, інформація у суспільстві «розсіяна» серед людей, і кожен індивід має частину цих знань, що досить часто носять неформальний, інтуїтивний характер [7]. Причому, розсіяність інформації визначається не лише тією обставиною, що вона розпорошена між окремими членами суспільства, а й тим, що вона часто перебуває в інтуїтивній, невербалізованій формі і усвідомлюється лише в процесі конкретної діяльності. В освітніх системах «розсіяною» інформацією $є$ дані про реальні освітні потреби як окремих людей (учнів, батьків, педагогів), так і громадських організацій, державних i самоврядних структур тощо, а також пропозиції щодо можливих шляхів їх задоволення. Тому вирішальну роль для успішного функціонування освітніх систем має їх здатність ефективно збирати й обробляти цю «розсіяну» інформацію, причому, саме на основі спільної, зокрема управлінської, діяльності, спрямованої на забезпечення сталого розвитку загальної середньої освіти.

М. Кастельс зауважує, у сучасному світі влада потоків інформації переважає над потоками влади [8]. Причому, саме мережна організація найбільше підходить для адекватної обробки потоків інформації, без чого неможливе ефективне управління системами.

У мережі кожна підсистема чи елемент (а́ктор) можуть бути пов’язані з іншими. Якщо кількість а́кторів - $n$, то максимальне число зв'язків між а́кторами $N_{\max } \epsilon$ таким:

$$
N_{\text {max }}=C_{n}^{2}=\frac{n !}{2 \times(n-2) !}=\frac{n \times(n-1)}{2} .
$$

Відповідно, максимальна кількість інформаційних потоків (зважаючи на їх двосторонню спрямованість) дорівнює $K_{i}=n \times(n-1)$, що при $n \geq 3$ значно більше від кількості інформаційних потоків в ієрархічних системах, де підсистеми пов'язані лише з керуючою підсистемою: $M_{i}=2 \times(n-1)$.

Отже, внаслідок мережного характеру взаємодій інформаційні потоки у громадських структурах значно інтенсифікуються, що $є$ характерним для громадськодержавного управління соціальними системами. Тобто, мережний характер управління в системі громадських структур забезпечує формування i розвиток громадськодержавного управління загальною середньою освітою в цілому.

Новітні засоби і технології інформаційно-комунікаційних мереж, зокрема Інтернет, як зазначає Биков В. Ю., забезпечують додаткові умови для розвитку процесів управління сучасною освітою [9]. Електронна пошта, WEB-сайти навчальних закладів 3 можливістю зворотного зв'язку, вебінари, соціальні, зокрема освітні, Інтернет-мережі, технології хмарних обчислень надають широкі можливості для обміну інформацією між державними, самоврядними, освітянськими, учнівськими, батьківськими і громадськими структурами щодо оцінювання сучасного стану освіти, існуючих проблем і шляхів їх подолання, визначення напрямів розвитку навчальних закладів на ближню, середню і далеку перспективи. 
Крім того, що сучасні інформаційно-комунікаційні мережі і технології хмарних обчислень, мають низку суттєвих технічних переваг, зокрема, забезпечують багатоканальне поповнення освітніх ресурсів i множинний доступ до них, уможливлюючи спілкування й організацію спільної діяльності [10], вони сприяють формуванню хмаро орієнтованих освітянських спільнот, які:

- упроваджують мережне мислення, що забезпечує перехід від егоцентричної позиції до розуміння ролі i значення інших людей, інших способів конструювання реальності;

- освоюють децентралізовані моделі і стратегії діяльності;

- розвивають, з одного боку, толерантність, що дозволяє подивитися на будь-яку подію з іншої точки зору, зрозуміти позицію іншої людини; а, з іншого, критичне мислення, що відіграє вирішальну роль у пошуку помилок, перевірці гіпотез і теорій $[11$, с. 6].

Отже, як бачимо, хмаро орієнтовані спільноти якнайповніше відповідають демократичному характеру громадсько-державного управління загальною середньою освітою в цілому і $є$ ще одним чинником розвитку громадської складової в управлінні сучасною освітою.

Авторська схема мережної взаємодії громадських, самоврядних і державних структур у громадсько-державному управлінні загальною середньою освітою [5] зображена на рис. 2.

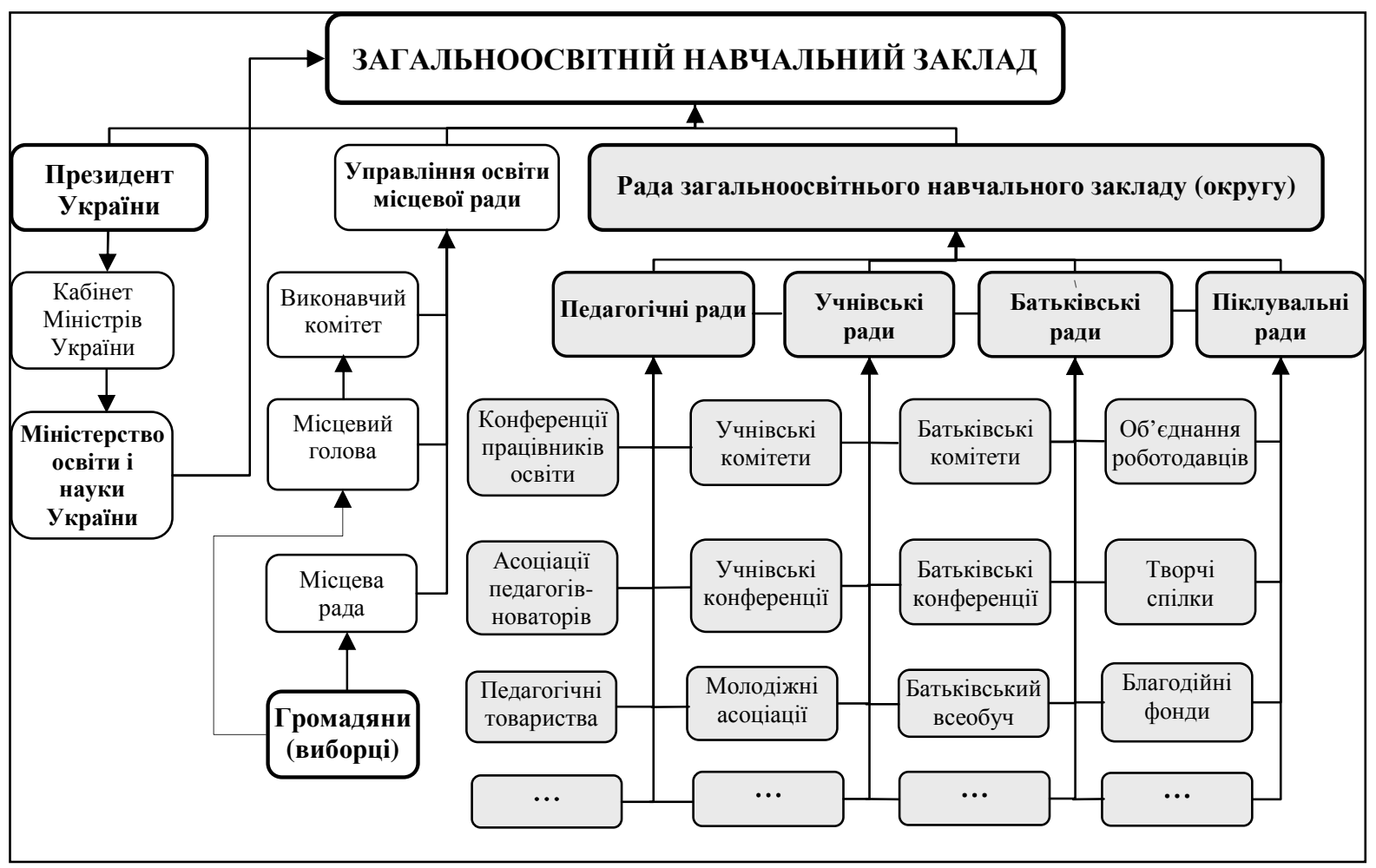

Рис. 2. Схема мережної взаємодї громадських, самоврядних і державних структур у громадсько-державному управлінні загальною середньою освітою

\section{4. ВИСНОВКИ ТА ПЕРСПЕКТИВИ ПОДАЛЬШИХ ДОСЛІДЖЕНЬ}

Проведений вище аналіз дає можливість сформулювати висновок: у сучасних умовах демократизації суспільно-політичного життя країни, активізації місцевого 
самоврядування, розвитку соціального капіталу й інформаційних технологій саме мережна взаємодія громадських управлінських структур у поєднанні 3 владною вертикаллю державних структур, збудованою згори донизу, і вертикаллю самоврядних, збудованою знизу догори, надасть системі управління загальною середньою освітою необхідної міри різноманітності і забезпечить освітнім системам як стійкість, так і можливості для ефективного розвитку.

Перспективи подальших досліджень даної проблеми пов'язані 3 вивченням конкретних шляхів модернізації організаційної, педагогічної, фінансово-економічної взаємодії державних, самоврядних і громадських структур в умовах формування та розвитку громадсько-державного управління загальною середньою освітою, зокрема, на основі застосування хмарних технологій.

\section{СПИСОК ВИКОРИСТАНИХ ДЖЕРЕЛ}

1. Шабров О. Ф. Социальное разнообразие как фактор эффективной политики в современном мире [Електронний ресурс] / О. Ф. Шабров // Тезисы докладов. V Всероссийский конгресс политологов «Изменения в политике и политика изменений: Стратегии, институты, акторы» (Москва, 20-22 ноября 2009 г.). - М. : Российская ассоциация политической науки, 2009. - С. 462-464. - Режим доступу : http://shabrov.info/Statji/raznoobr8.htm.

2. Эшби У. Р. Введение в кибернетику / У. Р. Эшби. - М.: Издательство иностранной литературы, 1959. - $432 \mathrm{c}$.

3. Шабров О.Ф. Государственное управление в России: проблемы эффективности [Електронний ресурс] / О. Ф. Шабров // Социально-гуманитарные знания. — 2005. — № 2. — Режим доступу : http://shabrov.info/Statji/gos_upr.htm.

4. Пастовенський О. В. Тенденції розвитку системи управління загальною середньою освітою в умовах зростання різноманітності освітніх систем / О. В. Пастовенський // Вісник Житомирського державного університету імені Івана Франка. — 2012. - Випуск 61. — С. 106-109.

5. Пастовенський О. В. Мережева модель управління загальною середньою освітою / О. В. Пастовенський // Рідна школа. - 2012. — № 6. - С. 13-18.

6. Чучкевич М. М. Основы управления сетевыми организациями / М. М. Чучкевич. — М.: Изд-во Института социологии, 1999. - 38 с.

7. Хайек Ф. А. Дорога к рабству / Ф. А. Хайек. - М. : «Экономика», 1992. — 176 с.

8. Кастельс М. Информационная эпоха: экономика, общество и культура [Електронний ресурс] / М. Кастельс // Библиотека Гумер-Политология. - Режим доступу: http://www.gumer.info/bibliotek_Buks/Polit/kastel/intro2.php.

9. Биков В. Ю. Технології хмарних обчислень — провідні інформаційні технології подальшого розвитку інформатизації системи освіти України / В. Ю. Биков // Комп’ютер у школі та сім’ї. 2011. — № 6. - С. 3-11.

10. Шишкіна М. П. Проблеми інформатизації освіти України в контексті розвитку досліджень оцінювання засобів ІКТ [Електронний ресурс] / М. П. Шишкіна, О. М. Спірін, Ю. Г. Запорожченко // Інформаційні технології і засоби навчання. - 2012. - № 1(27). — Режим доступу: http://www.journal.iitta.gov.ua.

11. Патаракин Е. Д. Социальные сервисы Веб 2.0 в помощь учителю / Е. Д. Патаракин. - [2-е изд., испр.]. - М. : Интуит.ру, 2007. - 64 с.

Матеріал надійшов до редакиї 10.06.2014 p.

\section{РАЗВИТИЕ СЕТЕВОГО ВЗАИМОДЕЙСТВИЯ ОБЩЕСТВЕННЫХ И ГОСУДАРСТВЕННЫХ СТРУКТУР В УПРАВЛЕНИИ ОБЩИМ СРЕДНИМ ОБРАЗОВАНИЕМ}

Пастовенский Александр Викторович

кандидат педагогических наук, начальник управления образования и науки Житомирская областная государственная администрация, г. Житомир, Украина ztedu@ukr.net 


\begin{abstract}
Аннотация. В статье рассмотрены тенденции развития системы управления общим средним образованием. Установлено, что эффективности управления образовательными системами можно достичь на основе делегирования управленческих функций от государства местному самоуправлению, образовательным и общественным структурам. Сделан вывод, что именно сетевое взаимодействие общественных управленческих структур с властной вертикалью государственных структур, построенной сверху вниз, и вертикалью местного самоуправления, построенной снизу вверх, смогут обеспечить образовательным системам возможности для активного развития. Подчеркнуто, что современные облачные технологии выводят сетевые взаимодействия государственных, образовательных и общественных структур, местного самоуправления в управлении средним образованием на качественно новый уровень.
\end{abstract}

Ключевые слова: государственные; образовательные; общественные структуры; местное самоуправление; сетевое взаимодействие; облачные технологии.

\title{
THE DEVELOPMENT OF NETWORK INTERACTIONS BETWEEN PUBLIC AND STATE STRUCTURES IN SECONDARY EDUCATION MANAGEMENT
}

\author{
Olexandr V. Pastovensky \\ $\mathrm{PhD}$ (pedagogical sciences), Head of Education and Science Department \\ Zhytomyr Regional State Administration, Zhytomyr, Ukraine \\ ztedu@ukr.net
}

\begin{abstract}
The developmental tendencies of secondary education management system are considered in the article. It was established, that an effective management of the educational systems can be attained on the basis of delegation of administrative functions from state to selfgovernmental, educational and public structures. The conclusion was made that the network interactions of the community management structures with vertical state structures being constructed from top to bottom, and the vertical of self-governing bodies being built from the bottom to the top, will provide the educational system with stability as well as the opportunities for effective development. It was emphasized, that modern cloud technology output network interactions of state, self-governmental, educational and public structures in the secondary education management to a new level.
\end{abstract}

Keywords: state, self-governmental, educational, public structures; network interactions; cloud technology.

\section{REFERENCES (TRANSLATED AND TRANSLITERATED)}

1. Shabrov O. F. Social diversity as a factor in effective policy in the modern world [online] / O. F. Shabrov // Abstracts. V All-Russian Congress of Political Scientists «Changes in policy and policy of changes: policies, institutions, actors» (Moscow, 20-22 November 2009). - Moscow : Russian Political Science Association, 2009. - P. 462-464. — Available from: http://shabrov.info/Statji/raznoobr8.htm (in Russian).

2. Ashby W. R. An Introduction to Cybernetics / W. R. Ashby. - M. : Izdatelstvo innostrannoi literatury, 1959. - 432 p. (in Russian).

3. Shabrov O. F. State Management in Russia: Problems of Efficiency [online] / O. F. Shabrov // Sotsialnogumanitarnyie znaniia. — 2005. — № 2. - Available from : http://shabrov.info/Statji/gos_upr.htm. (in Russian).

4. Pastovensky O. V. Tendencies of secondary education management system in the conditions of increase of educational systems variety / O. V. Pastovensky // Visnyk Zhytomyrskogo derzhavnogo universytetu imeni Ivana Franka. — 2012. — Vypusk 61. — P. 106-109. (in Ukrainian).

5. Pastovensky O. V. The network model of secondary education management / O. V. Pastovensky // Ridna shkola. - 2012. — № 6. -P. 13--18. (in Ukrainian).

6. Chuchkevich M. Basics Network Organizations / M. Chuchkevich. - M. : Izd-vo Instituta sotsiologii, 1999. - 38 p. (in Russian).

7. Hayek F. The Road to Serfdom / F. Hayek. — M. : «Ekonomika», 1992. — 176 p. (in Russian). 
8. Castells M. The Information Age: Economy, Society and Culture [online] / M. Castells // Biblioteka Gumer — Politologia. — Available from : http://www.gumer.info/bibliotek_Buks/Polit/kastel/intro2.php. (in Russian).

9. Bykov V. Yu. Cloud computing technology - the leading information technology for further development of information systems education in Ukraine / V. Yu. Bykov // Kompiuter u shkoli ta simi. — 2011. № 6. - P. 3-11. (in Ukrainian).

10. Shishkina M. Problems of Informatization of Education of Ukraine in context of development evaluating of ICT tools [online] / M. Shishkina, O. Spirin, G. Zaporozhchenko // Information technology and learning tools. — 2012. — № 1(27). — Available from : http://www.journal.iitta.gov.ua. (in Ukrainian).

11. Patarakin E. D. Web 2.0 social services to help the teacher / E. D. Patarakin. - [2-nd ed., Rev.]. Intuit.ru, 2007. - 64 p. (in Russian) 